\title{
Access to the Highest Administrative Courts: between the Right of an Individual to Have a Case Heard and the Right of a Court to Hear Selected Cases ${ }^{1}$
}

\author{
Wojciech Piątek \\ Adam Mickiewicz University, Poland \\ wojciech.piatek@amu.edu.pl \\ https://orcid.org/0000-0002-3494-1912
}

Received: 5.11.2019

Accepted: 13. 1. 2020

\section{ABSTRACT}

\begin{abstract}
Hearing a dispute by a court in a reasonable time is one of the crucial conditions for the existence of an effective judicial system as imposed by the European law and national legal orders. That requirement is contrary to the expectations of individuals to question the judgments of lower courts before the courts of the highest instance. The purpose of this article is to explore the question of values that should be taken into consideration by legislatures in a process of determining the access of administrative cases to the highest courts. The analysis is based on the example of Austrian and Polish legal systems. In both countries, there is a separate two-instance administrative judiciary. However, the conditions of the access to the Supreme Administrative Courts differ. In Poland, that access is unlimited, considering the constitutional principle of two-instance court proceedings. In Austria, the right in question is limited to cases deemed significant for broader interest, i.e. not only the one of the parties to the proceeding. An analysis of the normative consequences of each solution leads to the conclusion that procedural limitations concerning the access to the highest courts foster their role in preserving the uniformity of the case law and ensuring a high standard of its interpretation. A system with no limitations does not guarantee the determination of a concrete dispute in a reasonable time and thus cannot be considered effective.
\end{abstract}

Keywords: administrative courts, access to justice, court-administrative procedure, effective appeal and judicial protection, Austria, Poland

1 This paper was prepared within a project no UMO-2018/30/E/HS5/00421, financed by the National Science Centre, Poland, devoted to the appealability of administrative courts judgments. 


\section{Introduction}

Administrative courts perform a crucial role in a protection of an individual towards the public administration and in achieving high standards of the rule of law. Though the administrative judiciary is not present in all European law systems, ${ }^{2}$ in countries where it exists separately, is regarded as a basic institution responsible for an implementation of the principle of lawfulness. ${ }^{3}$ In that sense case-law of administrative courts affects an activity of public administration which should be based above all on the rule of law.

These special branches of administrative judiciary are present in Austria and in Poland for years. There are significant similarities between a structure of the system of judiciaries in these countries. A Polish model of the administrative judiciary was adopted after the First World War form one-instance Austrian Administrative Tribunal (Verwaltungsgerichtshof) , ${ }^{4}$ which was created in 1875 (Piatek and Skoczylas, 2016, pp. 11-12). Currently, the structure of the administrative judiciary in both counties is a two-instance. In Poland the last structural reform was carried out in $2002^{5}$ and in Austria in $2012 .{ }^{6}$ Besides the courts of first instance on the top of the judiciaries are created the highest administrative courts: VG in Vienna and the Supreme Administrative Court ${ }^{7}$ in Warsaw. ${ }^{8}$ The administrative judiciaries in both countries function in the same requirements of an effective judicial control, created by the EU-law and the Council of Europe. ${ }^{9}$

The aim of this paper is to answer questions, which values should be taken into consideration by legislators in a creation of access to the highest administrative courts? How should be created the procedural conditions of access to the highest administrative courts such as admissibility requirements of legal remedy, the basis of this remedy and procedure aimed at evaluation of the admissibility? The basis for the answer will be an analysis of the procedural and

2 There are even countries without separate administrative judiciary like Denmark, Norway, Iceland, Slovakia and Japan. See (Schei, 2014, pp. 3-4; Bröstl and Gajdošikova, 2015, p. 287; Kurishima, 2017, pp. 150-154).

3 These opinion is strongly represented in Austria and in Poland. See (Dorazil, 1966, p. 56; Tarno, 2006, pp. 24-25; Hauer, 2013, pp. 2-3; Olechowski, 2019, pp. 436-437).

4 Hence forth as VG.

5 See more (Hauser et al., 2003, pp. 11-15).

6 See more (Pabel, 2013; Olechowski, 2019, pp. 434-435).

7 Hence forth as SAC.

8 In Austria, besides the VG is created a Federal Finance Court (das Verwaltungsgericht des Bundes für Finanzen), which is competent in adjudication about complaints against decisions in tax matters. See more Kofler, G., Summersberger, W. (2014). Das Bundesgericht für Finanzen im System der Verwaltungsgerichtsbarkeit: Handbuch der Verwaltungsgerichtsbarkeit, ed. J. Fischer, K. Pabel, N. Raschauer, Wien, pp. 626-627. In Poland tax disputes are adjudicated by administratrative courts. In the SAC is created a special department for tax matters named financial chamber (izba finansowa).

9 The standards of effective judicial control are developed in the case-law of European Court of Justice (ECJ), European Court of Human Rights (ECtHR) and in the literature. From Austrian and Polish papers see: Storr, S., (2014). Die österreichische Verwaltungsgerichtsbarkeit im europäischen Kontext: Handbuch der Verwaltungsgerichtsbarkeit, ed. J. Fischer, K. Pabel, N. Raschauer, Wien, pp. 75-104, Florianowicz-Błachut, P., (2019). Działalność uchwałodawcza Naczelnego Sądu Administracyjnego a funkcja europejska sądu administracyjnego: Stosowanie prawa europejskiego w orzecznictwie sądowym, ed. T. Grzybowski, M. Sarnowiec-Cisłak, Warszawa, pp. 58-68. 
factual conditions of an access of the parties to this courts. Particular attention will be focused on the limitations of this right, their aims and consequences.

According to a preliminary thesis of this paper, an access to the highest courts should be limited only to selected cases, significant for the general legal order and for the functions performed by these courts. The open access to the court of the highest instance does not guarantee the highest standard of protection of individuals against unlawful administrative decisions. The supreme administrative courts should examine only selected cases, significant for legal order and proper functioning of public administration. The crucial importance has a solution how this access should be created and which role should perform in this process the parties of the proceeding, above all individuals?

The paper will be divided into three parts. In the first part will be analyzed functions of the supreme administrative courts, specified to Polish and Austrian legal orders. The second part will be devoted to an analysis of the procedural circumstances of an access to the highest administrative courts, both from European and national, Polish and Austrian perspectives. In the third part of this paper will be presented the practical consequences of the adopted procedural models.

\section{The role of the supreme administrative courts}

The administrative judiciary in Austria and in Poland creates a separate branch of courts, which are not linked with ordinary judiciary. ${ }^{10}$ In both countries on the top of the structure of administrative courts which is two-instance are located supreme courts with a seat in capital cities of each country. These courts are mostly responsible for the adjudication of appeal remedies from the judgments of the first instance administrative courts. Besides these obligations, VG and SAC perform other tasks significant for individuals and public administration, due to their structural position and high substantial judicial competences. Their constitutional position, which finds confirmation in the constitutions of both states ${ }^{11}$ gives a reason for analysing a role of the courts on the top of the structure of the judiciary.

The role of each court which is on the top of the structure of judiciary is specific. On the one hand, these courts perform judicial obligations as each court. In these courts are employed judges who enjoy independence and impartiality in adjudication. The courts are a part of the judicial power in each state, separated from other powers. On the other side, the judiciary of these courts

10 It is not possible to lodge a remedy from a judgment of administrative court to the ordinary court or even to the high court. The administrative and ordinary courts are in both countries structural and procedural separated. See Hauser R., Celińska-Grzegorczyk, K. (2016). Sądy administracyjne a system sądownictwa powszechnego: System prawa administracyjnego. Tom 10. Sądowa kontrola administracji publicznej, ed. R. Hauser, Z. Niewiadomski, A. Wróbel, Warszawa, pp. 99-131, Kodek, G. (2017). Verwaltungsgerichtsbarkeit und ordentliche Gerichtsbarkeit - Gemeinsamkeiten und Unterschiede: Grundfragen der Verwaltungs- und Finanzgerichtsbarkeit, ed. M. Holoubek, M. Lang, Wien, pp. 24-43.

11 See the Article 133 paragraph 1 the Austrian Bundes-Verfassungsgesetz (BGBl. Nr. 1/1930, idFNr. 164/2013, hence forth B-VG) and the Article 184 the Polish Constitution (Official Journal of Polish Law from 1997, nb 78, poz. 483 as am., hence forth as PC). 
has crucial importance, because of their structural position and authority towards lower branches of courts and other state authorities. Therefore in the literature is stressed a double function of this courts, private and public. ${ }^{12}$ The private function gives the parties of the proceeding a possibility to review the case again. The public function embraces other competences of the supreme courts, connected with shaping a uniform case-law and fulfilling other tasks imposed on courts by legislators. ${ }^{13}$

A relation between these two functions should be balanced in the sense, that each of them should not make the second role practical impossible to fulfill. It is clearly seen, if the court is burdened by the amount of appeals and cannot supervise properly its own case-law. It is obvious, that the procedural circumstances of an access to the supreme court should be adjusted to its personal abilities and housing conditions of the court. These requirements should not negate an obligation, that the supreme courts have to exercise judicial power in individual cases which give a reason to formulate a general interpretation concerning current legislation. The public function performed by these courts to a great extend will be groundless without the private function. There is also a connection between these two functions. Balancing between them serves to properly fulfill each of them.

The above mentioned functions are recognized in national doctrine of law which stress the special role of supreme administrative courts in Poland and in Austria as guardians of uniformity of case-law and its development (Hohenecker, 2014, p. 32), protectors of the rule of law (Olechowski, 2019, p. 443) or institutions which shape the legal culture in the best possible way (Jabloner, 2001, p. 144). Additionally, these courts affect not only the activity of public administration, but perceive an influence on legislation is some areas of administrative law (Hauser, 2011, pp. 11-16). In Poland the SAC is also regarded as the institution which supports the independence of the local self-government units (Tarno, 2006, pp. 29-30). The role of the supreme courts is undoubtedly positive. The level of affection of the supreme courts on the judiciary itself, individuals, public administration and legislation depends on many circumstances of the functioning of these courts which should be adapted to the tasks. Otherwise the positive role of these courts would be strongly limited.

12 See (Faber, 2013, pp. 88-89; Wiącek, 2016, pp. 1093-1095). See also literature from other countries (Lindblom, 2000, pp. 337-340; Stirn, 2017, p. 140).

13 The public functions of the Austrian Supreme Administrative Court are regulated in the Article 133 paragraph 1-2 B-VG. Partialy these function of the Polish Supreme Administrative Court is regulated in the Article 166 paragraph 3 of the Constitution and in the Law on proceedings before administrative courts, Official Journal of Polish Law from 2017, poz. 1369 as am. 


\section{The procedural conditions of an access to the supreme administrative courts}

\subsection{European standards of an access to the supreme administrative courts}

The regulation of EU-law and the standards adopted by the Council of Europe do not formulate circumstances for a general access to the courts which are on the top of the structure of administrative judiciary. Nevertheless, if a legislator creates a possibility to that access, it should not be illusory and theoretical, but effective. ${ }^{14}$

The basis for the access to the court are regulated in Article 6 and 13 European Convention. It should be also noted that Article 47 of the Charter of Fundamental Rights guarantees a right to an effective remedy. Each state is obligated to ensure the citizens real access to a court, which includes not only the right to initiate the proceeding but also the right to obtain a determination of a dispute by a court. ${ }^{15}$ Concentrating on the procedural side of that right, it is possible to create formal requirements which will be proportional to the aim of limitations and not violate an essence of the access. Such kind of limitations as time-limits governing the submission of documents or lodging of appeals, special requirements for that document are aimed at ensuring the proper administration of justice and comply with the principle of legal certainty. ${ }^{16} \mathrm{~A}$ requirement that an individual has to be represented by a lawyer in a proceeding before a court of the highest instance is not regarded as a violence against the analyzed standards. ${ }^{17}$ It is incumbent on the party of the proceeding to respect these rules and display special diligence in the defense of his interests. ${ }^{18}$ These rules should be clear and foreseeable for an individual. ${ }^{19}$ An excessive formalism in an interpretation of formal rules can prevent individuals from using an available remedy and making an access to a court too complicated. ${ }^{20}$ The same assessment was given to a strict construction to a procedural rule which prevented an individual's action being examined on the merits. ${ }^{21}$ The basic elements in the case-law of ECtHR which determine an admissible standard of formal requirements are "legal certainty" and "proper administration of justice". Transparent formalities of a remedy which are aimed at shaping circumstance for a determination in merits of a particular dispute are not regarded as too excessive to create real access to a court.

14 ECtHR, 12 February 2004, case no 47287/99, Perez v. France, paragraph 80, ECtHR, 23 March 2010, case no 15869/02, Cudak v. Lithuania, paragraph 58.

15 ECtHR, 26 November 2016, case no 76943/11, Lupeni Greek Catholic Parish and others v. Romania, paragraph 86.

16 ECtHR, 4 April 2019, case no 8981/14, Kunert v. Poland, paragraph 31.

17 ECtHR, 21 Dezember 2010, case no 18353/03, Kulikowski v. Poland, paragraph 60.

18 ECtHR, 10 February 2005, case no 69315/01, Sukhorubchenko v. Russland, paragraph 45.

19 ECtHR, 18 October 2010, case no 8863/06, Mushta v. Ukraine, paragraph 47.

20 ECtHR, 12 November 2002, case no 46129/99, Zvolskŷ and Zvolská v. Czech Republic, paragraph 51.

21 ECtHR, 5 April 2018, case no 40160/12, Zubac v. Croatia, рагagraph 97. 
Both European Convention and the Charter of Fundamental Rights does not guarantee a right to more than one instance proceeding and to set up courts of appeal. ${ }^{22}$ If that standard is shaped, a court should avoid extremities, such as "excessive formalism" and "excessive flexibility", which will eliminate requirements created for lodging an appeal. ${ }^{23} \mathrm{~A}$ proceeding before courts of highest instances can be limited only to certain grounds which will protect above all public interest like the uniformity of case law or cases of special state interests. Nevertheless also in such cases should be ensured a right of each party to be heard and to determine a case in merits. ${ }^{24}$ The determination of a case should also find its end in a final and binding judgment. A system of legal remedies should be limited in light of that guarantee which has both for individuals and public authorities great significance.

A right of an unlimited access to the supreme administrative courts is partially stated in the regulations of the Council of Europe. According to the Article B.4.i. of the recommendation (2004)20, ${ }^{25}$ at least in important cases a decision of a tribunal that reviews an administrative act should be subject to appeal to a higher tribunal, unless a case is directly referred to this tribunal in accordance with national legislation. In the explanatory memorandum to the directive, the formulation about "most important cases" is related e.g. with disputes involving heavy administrative sanctions. Simultaneously, there are pointed out concrete standards of judicial review. Firstly, the right to appeal should be recognized in a reasonable time-limit defined by the individual national system. Secondly, national law should specify the conditions of the appeal and the jurisdictions of appeal body. Thirdly, the appeal body must satisfy the requirements of the Article 6 European Convention. Fourthly, states should decide the extent to which appeals can be lodged with the higher courts. The last formulation leads to a conclusion, that the appeal authority cannot be the same as the highest authority in a structure of the courts. Each state has its own competence to shape a structure of courts and access to the highest/supreme court can be more limited than to the appellate authority.

In the European law is not formulated a right to general access to the highest courts. ${ }^{26}$ The standards are directed on an access to a court and only in the most important cases to the appeal bodies. Each state has a significant latitude in a creation of an access to the highest courts. The legal regulation in that area should not be arbitrary in the sense, that it should take into account general principles like the independence of the judicial authority, a right to a fair hearing, public nature of the proceeding, final and binding judgment.

22 ECtHR, 17 July 2012, case no 24197/10, Muscat v. Malta, paragraph 43.

23 ECtHR, 26 July 2007, case no 35787/03, Walchli v. France, paragraph 29.

24 ECtHR, 14 December 2006, case no 1398/03, Markovic and others v. Italy, paragraph 113-115.

25 Recommendation (2004)20 of the Committee of Ministers to member states on judicial review of administrative acts from $15^{\text {th }}$ December 2004. https://search.coe.int/cm/Pages/result_details.aspx?ObjectID=09000016805dba26 (access on $27^{\text {th }}$ July 2019).

26 In the literature is stated, that an excessively high number of appeals could compromise the exercise of the most fundamental function of this courts which is to ensure of the unity of law and to decide new and significant questions. See (Stern, 2017, p. 140). Towards a European Public Law, Oxford, pp. 140. 
A lack of a right to a general access to the supreme courts is connected with the private and public role of these courts. If an individual had an absolute right to lodge an appeal remedy to the supreme court, then the private function would make the realization of the public function visibly more difficult or even impossible. The final decision about a relation between these functions is leaft the legislators who determine a border between a right of an individual to hear a case and a right of a court to hear selected cases.

\subsection{Polish standards of an access to the SAC}

The standards of access to the SAC are regulated in the PC. According to Article 176 paragraph 1 of the PC, which is located in a chapter titled "courts and tribunals", each court-proceeding is at least two-instance. The principle knows no exceptions and is regarded in a doctrine of law as a public subjective right which has a procedural nature (Grzegorczyk and Weitz, 2016, pp. 1787-1788) and as a guarantee of a reliable process in making individual decisions (Garlicki, 2005, p. 2). A significance of that principle for an individual has theoretical grounds.

As a result of the presented principle, in the court-administrative procedure are present remedies that give a right to question a judgment issued by the court of the first instance (Wojewódzki Sad Administracyjny) to the court of the second instance, which is the SAC. That right knows no procedural limitations and exceptions besides an obligation to prepare a cassation remedy by a legal representative ${ }^{27}$ and indication the grounds of cassation, which can be each kind of violation of substantive or procedural right, if the infringement could have affected the outcome of the case. ${ }^{28}$ The broad scope of normative violations possible to appeal is confirmed in a special judgment of SAC, which has a binding force for all administrative courts. ${ }^{29}$ In this judgment the SAC has stated, that in cassation can be revived both the violations of administrative and court-administrative proceeding made by the court of the first instance. ${ }^{30}$ The SAC hears a case within the limits of the cassation complaint and takes into account ex offcio only grounds of invalidity of the proceeding. ${ }^{31}$

In reality, a party of the proceeding can formulate any charge connected with a violation of law by the administrative court of the first instance. The high standards of appealability of judgments of Polish administrative courts are followed by the Constitutional Tribunal. ${ }^{32}$ In its case-law appealability of judgments is perceived as a guarantee for individuals without exceptions, which could make an admissibility of a remedy too complicated or difficult. Concen-

\footnotetext{
27 Article 175 paragraph 1 the Law on Proceedings before administrative courts (Journal of Laws 2018, item 1302 as am., hereinafter as PPSA).

28 Article 174 PPSA.

29 According to the Article 269 paragraph 1 of the PPSA, if any panel of the administrative court hearing a case does not share the position taken in the resolution by seven judges, by a panel of the entire Chamber or by the full panel of the SAC, it shall submit the arising legal issue for resolution by an appropriate panel of SAC.

30 SAC, 26 October 2009, case no I OPS 10/09, ONSAiWSA 2010/1/1.

31 Article 183 paragraph 1 PPSA.

32 Hereinafter as CT.
} 
trating on the judgments of the CT based on the PPSA, the Tribunal negatively reviewed an interpretation of cassation basis which lead to inadmissibility of that remedy, because of formal mistakes in its creation. Such mistakes like an erroneous specification of a cassation basis, a violation of substantive law instead of procedural law, should not make a proceeding before the SAC impossible (falsa demonstratio non nocet). According to the Tribunal, attempts to acceleration of the procedure can not negate the right to two instances proceeding. ${ }^{33}$

In another judgment, the Tribunal stated, that a formal mistake made by a legal representative in preparations of a cassation cannot lead to inadmissibility of that remedy. The $\mathrm{CT}$ decided, that a party of a proceeding should not bear the negative consequences of not taking into consideration in a cassation complaint a request that a questioned judgment should be annulled or modified, together with indication of the scope of the requested annulment or modification. A rejection of an appeal without a summon to complete a formal mistake is in a view of the CT disproportionate. ${ }^{34}$ It is truth, that a legal representative should undertake only beneficial activities for his principal. From the nature of the power of attorney is known, that all activities of the legal representative, not only beneficial, are made in the name and on the principal's account. Making a distinction between positive and negative effects of the representation has no grounds based on CP and PPSA. Additionally it is contradictory with the principle of the equality of arms both parties of the procedure (Piątek, 2014, p. 177).

The case-law of the CT based on Article 176 paragraph 1 of the Polish Constitution made some proposals of improvement procedural limitations in an access to the SAC impossible. ${ }^{35}$ In 2012 was prepared a proposal to dismiss a cassation complaint by the SAC, if it is obvious, that there is a lack of justified grounds or a party abused the right of two-instance proceedings. From that decision issued in a panel of one judge a party would have a right to a complaint to the SAC, which would examine it in a panel of three judges (Kmieciak, 2012, p. 4). That proposal was not even taken to the Parliament because of critical assessments from former judges of the CT.

\subsection{Austrian standards of an access to the VG}

In a contrast to the Polish constitution, the Austrian Bundesverfassungsgeset ${ }^{36}$ does not contain a right to a two-instance court-proceeding, though the constitutional regulation about administrative courts (Verwaltungsgerichtsbarkeit ${ }^{37}$ ) is much more detailed as in the PC. The structure of administrative courts is

33 CT, 20th September 2006, Case SK 63/06, OTK-A 2006/8/108.

34 CT, $8^{\text {th }}$ April 2014, Case SK 22/11, OTK-A 2014/4/37.

35 The same reason can be concluded from the case-law of CT on a basis of the civil and criminal procedures. See CT 12nd March 2002, Case P 9/01, OTK-A 2002/2/14, CT 13 th January 2004, Case SK 10/03, OTK-A 2004/1/2, CT 20 $0^{\text {th }}$ May 2008, Case P 18/07, OTK-A 2008/4/61, CT $14^{\text {th }}$ September 2009, SK 47/07, OTK-A 2009/8/122.

36 Bundesverfassungsgestez (BGBI. Nr. 1/1930 as am., hereinafter as B-VG).

37 The articles 129-136 are located in the seventh part of the B-VG, titled "Constitutional and administrative guarantees", nb A. Administrative courts (Verwaltungsgerichtsbarkeit). 
two-tried. On a first level adjudicate administrative courts, after one of the nine of federal states, the Federal Administrative Court (Bundesverwaltungsgericht) and the Federal Finance Court (Bundesfinanzgericht). This structure is named as a model 9+2 and is created in 2012, in a result of a reform of administrative judiciary. ${ }^{38}$ On the top of the structure of the Austrian administrative courts is the VG (Verwaltungsgerichtshof), as a court of second instance with a scope of jurisdiction regulated in Article 133 paragraph 1 B-VG and limited regarding to the appeal remedy (Revision) in Article 133 paragraph 4 B-VG.

An access to the VG in the scope of the appeal remedy is limited to the questions of law in a concrete dispute which are of particular importance. ${ }^{39}$ In Article 133 paragraph 4 B-VG are stated concrete examples where such a question arises. These are connected with not unanimous adjudication of administrative courts, first of all the VG. ${ }^{40}$ From that sense, an appeal remedy is admissible if a judgment of the first-instance court is divergent from the case-law of the $\mathrm{VG}^{41}$ or its case-law in a concrete area is not uniform or such kind of legal dispute was not adjudicated by the VG. ${ }^{42}$ If the case-law of the first-instance court has not a new content which will be significant for the whole case-law or the law interpretation, appeal remedy should be disqualified (Handstanger, 2015, pp. 679-680). In each of these premises a public interest is predominant towards a private interest in the sense, that without proving one of the premises it is impossible to initiate an instance control of a judgment of the first-instance court. The premises are connected with the creation of the case-law of administrative courts, either its uniformity or case-law in new areas of law. ${ }^{43}$ In other words, the fulfillment of the private function of VG is combined with the public function. For each case the private function has to be supplemented by the public.

The procedural conditions for the admittance of the appeal remedy are regulated in the statute about the Administrative Tribunal (Verwaltungsgerichtshofgesetz). ${ }^{44}$ Each appeal as a document should contain concrete elements

38 More about the reform of the administrative judiciary in Austria see (Steiner, 2014, pp. 117132; Holoubek, 2017, pp. 18-20).

39 The competences for examination of the merits of a concrete case are a basis for an opinion, that the Administrative Tribunal is a court in a sense of the Article 47 of the Charter of Fundamental Rights and the Article 6 of the European Convention. See Grabenwarter, Ch., Fister, M., (2014). Verwaltungsverfahrensrecht und Verwaltungsgerichtsbarkeit, Wien, pp. 261.

$40 \mathrm{~A}$ protection of an individual in the proceeding before the Administrative Tribunal is in the background. See Kahl, A., (2014). Rechtsschutz gegen Entscheidungen der Verwaltungsgerichte erster Instanz beim VwGH: Handbuch der Verwaltungsgerichtsbarkeit, ed. J. Fischer, K. Pabel, N. Raschaver, Wien, pp. 435.

41 A particular importance of a case can be also connected with a necessity of deepening the existing case-law of the Administrative Tribunal. See more Kahl, A. (2014). Rechtsschutz gegen Entscheidungen der Verwaltungsgerichte erster Instanz beim VwGH: Handbuch der Verwaltungsgerichtsbarkeit, ed. J. Fischer, K. Pabel, N. Raschauer, Wien, pp. 438.

42 It is not significant if that inconsistence comes from substantive or procedural law and concerns all areas of administrative law. See Faber, R., (2013). Verwaltungsgerichtsbarkeit, Wien, p. 92.

43 In the last sentence of the Article 133 paragraph 4 B-VG is stated other condition for a limitation of appeal remedies connected with a small value of the subject-matter of review. These competition is passed on the legislator who determined such limitation in the Article 25a paragraph 4 VwGG. For cash punishment imposed by an administrative authority these limitation is on the level of 750 Euro and for judgments of the court of the first instance 400 Euro.

44 Verwaltungsgerichtshofgesetz (BGBl. Nr. 10/1985 as am., hereinafter asVwGG). 
connected with the details of a concrete case and parties of a dispute. The most significant element is an obligation for a petitioner to write grounds of appeal, which are concrete violations of law made by a court of first instance. ${ }^{45}$ There are two types of the appeal remedies, ordinary (ordentliche Revision) and extraordinary (außerordentliche Revision). ${ }^{46}$ A difference between them is located in an art of an admittance of that legal remedy by the court of the first instance. Though an ordinary remedy is lodged after an admittance granted by the court of first instance, an extraordinary remedy is lodged to the VG without that. Therefore in that document the grounds of appeal have to be supplemented by the grounds which refer to Article 133 paragraph 4 B-VG.

An admittance of an appeal remedy is granted by an administrative court together with an issuing of a judgment and needs a short justification. ${ }^{47}$ The VG is not bound by the decision of the court of first instance ${ }^{48}$ and can dismiss an appeal remedy in camera with a form of an order. ${ }^{49}$

An extraordinary appeal remedy is lodged to the court of first instance and after serving copies of the remedy to the parties of a dispute and the competent Ministry, passed to the VG which leads an initial and in merits proceeding. ${ }^{50}$ The grounds of these appeal should not be directed against an order of the administrative court about the inadmissibility of the remedy, but against the judgment of the court of the first instance which is appealed (Kahl, 2014, p. 440). A reference to other documents is not acceptable (Grabenwarter, 2014, p. 274). The Tribunal will examine the grounds of appeal remedy with the premises from Article 133 paragraph 4 B-VG. ${ }^{51}$ The same like with an ordinary appeal remedy, it can be settled as inadmissible by an order or remand to the adjudication in merits.

There are also other competences of the VG regulated in the Article 133 paragraph 1 B-VG. Besides the determination of the appeal remedies, the VG is competent in application for setting the date for the settlement of the case by the court of first instance, after expiring that term and resolving jurisdictional disputes between administrative courts or administrative courts and the VG. These competences are exhaustive (Faber, 2013, pp. 88-89). ${ }^{52}$ In connection to the both additional activities of the VG there are visible connections to the competences the SAC which adjudicate about excessive course

45 Article 28 paragraph 1 point 5 VwGG. The Administrative Tribunal besides a control over a competence of administrative courts and a violation of procedural law, according to the Article 41 is limited in adjudication to the grounds of appeal.

46 It is worth mentioning, that in the practice of the Administrative Tribunal, the extraordinary appeal remedies are majority towards the ordinary. In 2018 the ordinary appeal remedies was only $7 \%$ of all motions lodged to the Tribunal, whereas the extraordinary appeal remedies was $88 \%$. See Information about activity of the Administrative Tribunal in 2018, p. 18. https:// www.vwgh.gv.at/medien/mitteilungen/taetigkeitsbericht2018_190705_\%5BWEB\%5D.pdf ?72qkz6 (access on $27^{\text {th }}$ July 2019).

47 Article 25a paragraph 1 VwGG.

48 Article 34 paragraph 1a VwGG.

49 Article 34 paragraph 1 VwGG.

50 Article $30 a$ paragraph 7 VwGG.

51 Article 34 paragraph 1a VwGG.

52 The competences not embrace the jurisdiction of the Constitutional Court. See more (Grabenwarter and Fister, 2014, pp. 258-259). 
of proceeding before administrative authorities and resolve jurisdictional disputes between local government authorities and self-government appellate boards. ${ }^{53}$ In these competences is realized the public function of the highest administrative courts.

\section{The consequences of the presented procedural conditions}

\subsection{Polish experiences}

A result of no deep procedural amendments in PPSA and a broad access to the SAC is the pending time of the proceeding before the SAC. According to available statistics, published annually by the SAC in the form of reports on the activity of administrative courts, the pending time for examining the cassation remedy in the court-administrative proceeding is gradually longer. The available figures indicate that in 2004 the SAC arranged, within 12 months, 2872 (47.3\%) of cassation complaints, ${ }^{54}$ in $2010-10922$ (49.6\%) of cassation complaints, ${ }^{55}$ in 2015 - 14892 (26.45\%) of cassation complaints, ${ }^{56}$ in 2017 - 19192 $(27.96 \%)^{57}$ and in $2018-18897(36,45 \%) .{ }^{58}$ Over a period of less than 15 years, the waiting time for the SAC to hear cassation complaints has been extended, which currently amounts around 1,5 year and for disputes heard at trial it is approximately even longer, till 2 years. ${ }^{59}$ Adopting the method of measuring the length of pending time in the SAC (disposition time), ${ }^{60}$ in 2004 the average pending time amounted 406 days (13,3 months), in 2015 - 633 days (20,8 months), in 2017 - 502 days (16,5 months), in 2018 - 531 days (17,4 months).

The basic reason for the prolonging pending time in the proceeding before the SAC is the gradually increasing number of cassations lodged against judgments of voivodship administrative courts. While in 2004, the SAC received

53 See more about this competence in Skoczylas, A., (2008). Rozstrzyganie sporów kompetencyjnych i sporów o właściwość przez NSA, Warszawa.

54 Information about activity of administrative courts in 2004, Warszawa 2005, p. 23 (access on $27^{\text {th }}$ July 2019).

55 Information about activity of administrative courts in 2010, Warszawa 2011, p. 16 (access on $27^{\text {th }}$ July 2019).

56 Information about activity of administrative courts in 2015, Warszawa 2016, p. 22-23 (access on $27^{\text {th }}$ July 2019).

57 Information about activity of administrative courts in 2017, Warszawa 2018, p. 22 (access on $27^{\text {th }}$ July 2019$)$.

58 Information about activity of administrative courts in 2018, Warszawa 2019, p. 19 (access on $27^{\text {th }}$ July 2019).

59 The information reports about activity of administrative courts do not contain the average disposition time for proceedings before administrative courts of first instance and before the SAC.

60 The disposition time is obtained by dividing the number of pending cases at the end of the observed period by the number of resolved cases within the same period multiplied by 365 (days in a year). See more in: European judicial systems. Efficiency and quality of justice. CEPEJ Studies. No. 26, p. 238. https://rm.coe.int/rapport-avec-couv-18-09-2018-en/16808def9c (access on $13^{\text {th }}$ October 2019). 
6,471 cassation complaints, ${ }^{61}$ in 2010: $11,676,{ }^{62}$ in 2015: $14,634,{ }^{63}$ in 2017: $17,746^{64}$ and in 2018: $20229 .{ }^{65}$ In 2018 the cassations were lodged to the SAC more than three times as much as in comparison to 2004.

It is also truth that the number of solved cases from 2004 (2872) till 2018 (18897) is significantly increased, more than six times. In that period the number of judges in SAC is increased only from 64 till 107, less than two times. ${ }^{66}$ The reasons for the increased number of cases are different, normative and factual. Firstly, the judges are obliged to solve more cases. ${ }^{67}$ Secondly, more cases are solved not with public hearing, but in camera. ${ }^{68}$ Thirdly, almost in each panel in the SAC is present one judge delegated from the first instance administrative court. ${ }^{69}$ For that reason, it is possible to create more panels.

The presented data show that the organizational effort undertaken by the SAC expressing itself in an increasing number of cassation complaints does not translate into acceleration of pending time for their hearing. That effort does not stop the increasing amount of cassation complaints which are waiting for determination by the SAC. There are necessary other measures which make the procedure before administrative courts in Poland more effective. Besides the organizational measures, which has been already done, the legislative measures aimed at limitation the number of cassation appeals should be undertaken.

\subsection{Austrian experiences}

The normative regulation finds its consequences not only in Poland, but the same in Austria. In comparison to 2014, when a new regulation in Austria came into force, ${ }^{70}$ the number of pending cases at the end of each year is

61 Information about activity of administrative courts in 2004, Warszawa 2005, p. 22 (access on $27^{\text {th }}$ July 2019).

62 Information about activity of administrative courts in 2010, Warszawa 2011, p. 16 (access on $27^{\text {th }}$ July 2019).

63 Information about activity of administrative courts in 2015, Warszawa 2016, p. 22 (access on $27^{\text {th }}$ July 2019).

64 Information about activity of administrative courts in 2017, Warszawa 2018, p. 21 (access on $27^{\text {th }}$ July 2019).

65 Information about activity of administrative courts in 2018, Warszawa 2019, p. 19 (access on $27^{\text {th }}$ July 2019).

66 The current number of judges of the SAC is available on the website of the SAC http://www. nsa.gov.pl/sedziowie-nsa.php (access on $13^{\text {th }}$ October 2019).

67 For each session with public hearing there are four cases which should be solved by each judge. If there are similar cases, this amount may rise. The number of cases heard in camera is not strictly determined and depends on presiding judge of each department.

68 It is possible specially after the amendment of the proceeding before the SAC which was approved in 2015. See more Hauser, R., Skoczylas, A., Piątek, W. (2015). Środki odwoławcze w postępowaniu sądowoadministracyjnym w świetle ustawy nowelizującej z dnia 9 kwietnia 2015 r. - analiza najistotniejszych zmian, Zeszyty Naukowe Sądownictwa Administracyjnego, 4, pp. $19-20$.

69 The competence for such delegation is reserved for the President of the SAC, who may decide upon the consent of a judge to perform, for a definite period, the duties of a judge in the SAC. See the Article 13 para. 1 of the Law on the System of Administrative Courts (Journal of Laws from 2017, pos. 2188 as am.).

70 The new regulation was passed in 2012 and came into force at $1^{\text {st }}$ Januar 2014. 
being reduced and therefore time for hearing a case by the VG became significantly shorter.

In 2014 the VG dealt with proceedings initiated before $1^{\text {st }}$ January 2014, based on a former regulation and from the beginning of that year, according to new, presented above principles. From previous years the Tribunal has to deal with 4.623 proceedings. In the whole 2014 were lodged 3.938 new appeal remedies. The VG served 5.479 proceedings. For the next year remained 3.082 proceedings. ${ }^{71}$ The waiting period for hearing appeal remedies is gradually decreasing. That phenomenon is a result of the reform of Austrian administrative judiciary in 2012. The balancing between private and public functions of the VG came to a result, that each function is carried out properly.

The number of remained proceedings for a next year was constantly smaller and at the end of 2018 amounted 2.696 proceedings. ${ }^{72}$ An exception to that trend was 2017, when this number increased in comparison to the end of 2016 about 682 proceedings. ${ }^{73}$ As justification to that trend should be taken into account an increasing number of new proceedings in 2017, which was bigger in comparison to the whole 2016 about 43\%. ${ }^{74}$ The increasing number of appeal remedies is a similar phenomenon to the Polish observations. It can be understood as a general tendency for applying for courts protection, which is visible also from data presented by courts in other countries. ${ }^{75}$

The number of new proceedings initiated before the VG from 2014 till 2018 was constantly growing up, from 3.938 in 2014 till 7.873 in 2018. In each year was increased the number of resolved proceedings, from 5.479 in 2014 till 7.998 in $2018 .{ }^{76} \mathrm{~A}$ number of judges at the end of 2018 , in comparison to the end of 2014 was increased only about one position from the $11^{\text {st }}$ July $2018{ }^{77}$ from 53 to 54. As a result of that effort in examination of more proceedings, a waiting time for hearing a case before the $\mathrm{VG}$ is constantly decreasing from 10,6 months in 2014, till 8,9 in 2015, 6,9 in 2016, 4,6 in 2017 till 4,1 in 2018. ${ }^{78}$

71 Information about activity of the Administrative Tribunal in 2014, p. 17. https://www.vwgh. gv.at/gerichtshof/taetigkeitsberichte/taetigkeitsbericht2014.pdf?6rl096 (access on $27^{\text {th }}$ July 2019).

72 Information about activity of the Administrative Tribunal in 2018, p. 19. https://www.vwgh. gv.at/medien/mitteilungen/taetigkeitsbericht2018_190705_\%5BWEB\%5D.pdf?72qkz6 (access on $27^{\text {th }}$ July 2019).

73 Exactly from 2.139 proceedings at the end of 2016 till 2.821 at the end of 2017 . Information about activity of the Administrative Tribunal in 2017, p. 16. https://www.vwgh.gv.at/gerichtshof/taetigkeitsberichte/taetigkeitsbericht2017.pdf?6rloha (access on $27^{\text {th }}$ July 2019).

74 Information about activity of the Administrative Tribunal in 2017, p. 4. https://www.vwgh. gv.at/gerichtshof/taetigkeitsberichte/taetigkeitsbericht2017.pdf?6rl0ha (access on $27^{\text {th }}$ July 2019).

75 F.g. in Sweden in 2014 was lodged 7036 cases and in 2015 - 7369 . See administrative justice in Europe. Report from Sweden., p. 17. See https://www.domstol.se/hogsta-forvaltningsdomstolen/Funktioner/English/Publications-in-English/ (access on 17th October 2019).

76 Information about activity of the Administrative Tribunal in 2018, p. 16. https://www.vwgh. gv.at/medien/mitteilungen/taetigkeitsbericht2018_190705_\%5BWEB\%5D.pdf?72qkz6 (access on $27^{\text {th }}$ July 2019 ).

77 Information about activity of the Administrative Tribunal in 2018, p. 9. https://www.vwgh. gv.at/medien/mitteilungen/taetigkeitsbericht2018_190705_\%5BWEB\%5D.pdf?72qkz6 (access on $27^{\text {th }}$ July 2019 ).

78 Information about activity of the Administrative Tribunal in 2018, p. 19. https://www.vwgh. gv.at/medien/mitteilungen/taetigkeitsbericht2018_190705_\%5BWEB\%5D.pdf?72qkz6 (ac- 


\section{Wojciech Piątek}

This outcome is different to the Polish experiences. It is linked with the improvement of limitations to the procedure before the VG and selection of cases only for these which have a significance for public interest.

\section{Conclusion}

The analysis of the two systems of an access to the supreme administrative courts in Austria and in Poland presented both similarities and differences. The similarities are connected with structural position, tasks and functions performed by these courts. In Austria and in Poland the control over public administration is concentrated on the second-instance level in one court which is on the top of the administrative judiciary. The courts besides examination of appeal remedies are responsible for the uniformity and development of case-law. They exercise also other functions, such as determination of the competence disputes in public administration.

The differences are connected with procedural standards of judicial review of the courts of first instance. The SAC is a classical court of the second instance, because of the principle of two-instance court-proceeding. In Austria that principle not exist and an access to the VG is much more limited and connected with the public function of this court. Because of the balancing between private and public function, the factual access to the VG is more realistic than to the SAC. The activity of the VG is focused only on these disputes which are significant for the whole administrative judiciary, the quality of its case-law and the responsibility for the existence of the rule of law in the state.

In an access to the administrative judiciary should be taken into consideration values significant for the whole system of public entities, both public administration and courts. An unlimited access is not profitable for them, because the administrative judiciary is overloaded with typical cases and cannot properly react for the violations of law at the level of public administration. An unreasonable time for hearing particular cases is also inconvenient for individuals who often apply for court protection in concrete factual conditions and cannot wait two years for a final verdict. The Austrian regulation with the basis for the admissibility of revision gives a solution for such organization of the VG in order to use the knowledge and experience of this court in an effective way.

In a creation of requirements of an access to the highest administrative courts a legislator should take into consideration not only procedural but also factual standards. Receiving a final judgment in a reasonable time is significant for the economic interests of individuals and for fulfilling tasks performed by public administration. A great importance have factual possibilities of these courts, which are linked to the number of judges and other court's staff. For the courts of the highest instance it is also beneficial, if the relation between private and public functions is balanced. Contemporary that relation is disturbed in the Polish administrative judiciary. Though the speediness of the proceeding is not the only factor which determinates the effectiveness of the

cess on $27^{\text {th }}$ July 2019). 
proceeding, the unreasonable time of court proceeding makes the judicial control illusory.

Prolonged waiting time for the determination of concrete cases is harmful for the functions performed by the supreme administrative courts. ${ }^{79}$ In a final result a delay in determination of cassation appeals in Poland reduces the practical importance of the court's decisions. It requires reforms which will make the system more practical for individuals. The final conclusion of this paper is not based on a necessity of an adoption the Austrian regulations into the Polish system. Each state should create its own solution of an access to the highest courts which will remain in accordance with the international standards of the rule of law. An Austrian amendment from 2012 is an exemplification how that process can be realized. 


\section{References}

Bröstl, A. and Gajdošiková, L. (2015). Die Verwaltungsgerichtsbarkeit in der Slowakei. Osteuropa-Recht, 3, pp. 270-286.

Dorazil, W. (1966). Die Funktion der Verwaltungsgerichtsbarkeit in Österreich: 90 Jahre Verwaltungsgerichtsbarkeit in Österreich. Wien, pp. 56-60.

Faber, R. (2013). Verwaltungsgerichtsbarkeit. Wien: Verlag Österreich.

Florianowicz-Błachut, P. (2019). Działalność uchwałodawcza Naczelnego Sądu Administracyjnego a funkcja europejska sądu administracyjnego. In T. Grzybowski and M. Sarnowiec-Cisłak, eds., Stosowanie prawa europejskiego w orzecznictwie sądowym. Warszawa, pp. 55-68.

Grabenwarter, C. and Fister, M. (2014). Verwaltungsverfahrensrecht und Verwaltungsgerichtsbarkeit. Wien: Verlag Österreich.

Grzegorczyk, P. and Weitz, K. (2016). Komentarz do art. 78. In I. Tom et al., eds., Komentarz do Konstytucji RP. Warszawa: C.H. Beck, pp. 1784-1818.

Handstanger, M. (2015). 20 Monate Verwaltungsgerichtsbarkeit neu. Zeitschrift der Verwaltungsgerichtsbarkeit, 8, pp. 679-688.

Hauser, A. (2013). Gerichtsbarkeit des öffentlichen Rechts. Linz: Pedell.

Hauser, R. et al. (2003). Dwuinstancyjne sądownictwo administracyjne. Omówienie podstawowych zasad i instytucji procesowych. Teksty aktów prawnych. Warszawa-Zielona Góra: Zachodnie Centrum Organizacji.

Hauser, R. (2011). Orzecznictwo sądowo administracyjne a proces legislacyjny. Zeszyty Naukowe Sądownictwa Administracyjnego, 6, pp. 9-17.

Hauser, R. and Celińska-Grzegorczyk, K. (2016). Sądy administracyjne a system sądownictwa powszechnego: System prawa administracyjnego. In R. Hauser et al., eds., Sądowa kontrola administracji publicznej. Warszawa: C.H. Beck, pp. 99-131.

Hauser, R. et al. (2015). Środki odwoławcze w postępowaniu sądowoadministracyjnym w świetle ustawy nowelizującej z dnia 9 kwietnia 2015 r. - analiza najistotniejszych zmian. Zeszyty Naukowe Sądownictwa Administracyjnego, 4, pp. 9-21.

Holoubek, M. (2017). Alte und neue Grundfragen der Verwaltungsgerichtsbarkeit: Grundfragen der Verwaltungs- und Finanzgerichtsbarkeit In M. Holoubek and M. Lang, eds., Grundfragen der Verwaltungs- und Finanzgerichtsbarkeit. Wien: Lindeverlag, pp. 1-21.

Jabloner, C. (2001). Rechtskultur und Verwaltungsgerichtsbarkeit. Juristische Blätter, 3, pp. 137-144.

Kahl, A. (2014). Rechtsschutz gegen Entscheidungen der Verwaltungsgerichte erster Instanz beim VwGH. In J. Fischer et al., eds., Handbuch der Verwaltungsgerichtsbarkeit. Wien: Jan Sramek Verlag, pp. 433-453.

Kmieciak, Z. (2012). Projekt regulacji prawnej dotyczącej wstępnego badania skargi kasacyjnej w postępowaniu przed NSA. Europejski Przegląd Sądowy, 4, pp. 4-10.

Kodek, G. (2017). Verwaltungsgerichtsbarkeit und ordentliche Gerichtsbarkeit - Gemeinsamkeiten und Unterschiede. In M. Holoubek and M. Lang, eds., Grundfragen der Verwaltungs- und Finanzgerichtsbarkeit. Wien: Lindeverlag, pp. 23-43. 
Kofler, G. and Summersberger, W. (2014). Das Bundesgericht für Finanzen im System der Verwaltungsgerichtsbarkeit. In J. Fischer et al., eds., Handbuch der Verwaltungsgerichtsbarkeit. Wien: Jan Sramek Verlag, pp. 623-651.

Kurishima, T. (2017). Die Janusköpfigkeit des OGH als Revisions- und Verfassungsgericht. Zeitschrift für Japanisches Recht, 44, pp. 143-198.

Olechowski, T. (2019). Verwaltungsgerichtsbarkeit in Österreich. In A. Bogdany and P.M. Huber, eds., Handbuch lus Publicum Europaeum. Band VIII. Verwaltungsgerichtsbarkeit in Europa: Institutionen und Verfahren. Karlsruhe: C.F. Müller, pp. 419-473.

Pabel, K. (2013). Verwaltungsgerichtsbarkeit NEU. Textausgabe mit Erläuterungen. Wien: Lindeverlag.

Piątek, W. and Skoczylas, A. (2016). Geneza, rozwój i model sądownictwa administracyjnego w Polsce: System Prawa Administracyjnego. In R. Hauser et al., eds., Sądowa kontrola administracji publicznej. Warszawa: C.H. Beck, pp. $1-70$.

Piątek, W. (2014). Glosa do wyroku TK z dnia 8 kwietnia 2014 r., SK 22/11. Zeszyty Naukowe Sądownictwa Administracyjnego, 4, pp. 172-181.

Recommendation. (2004). of the Committee of Ministers to member states on judicial review of administrative acts from $15^{\text {th }}$ December 2004.

Schei, T. (2014). The independence of courts and judges and their relationship with the other branches of government. In N.A. Engstad et al., eds., The independence of judges. Hague: Eleven International Publishing, pp. 3-18.

Skoczylas, A. (2008). Rozstrzyganie sporów kompetencyjnych i sporów o właściwość przez NSA. Warszawa: Lexis Nexis.

Steger, A. (2008). Überlange Verfahrensdauer bei öffentlich-rechtlichen Streitigkeiten vor deutschen und europäischen Gerichten. Schriften zum Öffentlichen Recht, 1105. Duncker \& Humblot Berlin.

Steiner, W. (2014). Systemüberblickzum Modell $>9+2<$. In J. Fischer et al., eds., Handbuch der Verwaltungsgerichtsbarkeit. Wien: Jan Sramek Verlag, pp. 105-146.

Storr, S. (2014). Die österreichische Verwaltungsgerichtsbarkeit im Europäischen Kontext. In J. Fischer et al., eds. Handbuch der Verwaltungsgerichtsbarkeit. Wien: Jan Sramek Verlag, pp. 71-104.

Tarno, J.P. (2006). Sądowa kontrola administracji publicznej, jej geneza i funkcje - pojęcia ogólne. In J.P. Tarno et al., eds., Sądowa kontrola administracji. Podręcznik akademicki. Warszawa: Europejska Wyższa Szkoła Prawa i Administracji, pp. 19-30.

Wiącek, M. (2016). Komentarz do art. 184: Konstytucja RP. In L. Bosek and M. Safjan, eds., Komentarz. Tom II. Warszawa: C.H. Beck, pp. 1084-1108. 